\title{
Future Directions of Marine Myxobacterial Natural Product Discovery Inferred from Metagenomics
}

\author{
Ronald Garcia ${ }^{1,2}$, James J. La Clair ${ }^{3}$ (iD) and Rolf Müller 1,2,4,* \\ 1 Department of Microbial Natural Products (MINS), Helmholtz Institute for Pharmaceutical Research \\ Saarland (HIPS)—Helmholtz Centre for Infection Research (HZI), Campus E8 1, \\ 66123 Saarbrücken, Germany; ronald.garcia@helmholtz-hips.de \\ 2 German Center for Infection Research (DZIF), Partner site Hannover-Braunschweig, Inhoffenstrasse 7, \\ 38124 Braunschweig, Germany \\ 3 Xenobe Research Institute, P.O. Box 3052, San Diego, CA 92163-1052, USA; i@xenobe.org \\ 4 Department of Pharmacy, Saarland University, Campus E8 1, 66123 Saarbrücken, Germany \\ * Correspondence: rolf.mueller@helmholtz-hzi.de; Tel.: +49-681-98806-3000
}

Received: 31 July 2018; Accepted: 23 August 2018; Published: 29 August 2018

\begin{abstract}
Over the last two decades, halophilic (organisms that thrive at high salt concentrations) and halotolerant (organisms that have adapted to high salt concentrations) myxobacteria emerged as an important source of structurally diverse secondary metabolites from the marine environment. This review explores the advance of metagenomics analysis and $16 \mathrm{~S}$ rRNA gene phylogeny of the cultured and uncultured myxobacteria from marine and other salt-environments up to July 2018. The diversity of novel groups of myxobacteria in these environments appears unprecedented, especially in the Sorangiineae and Nannocystineae suborders. The Sandaracinaceae related clade in the Sorangiineae suborder seems more widely distributed compared to the exclusively marine myxobacterial cluster. Some of the previously identified clones from metagenomic studies were found to be related to the Nannocystineae suborder. This understanding provides the foundation for a vital, unexplored resource. Understanding the conditions required to cultivate these yet "uncultured" myxobacteria in the laboratory, while a key next step, offers a significant potential to further expand access to diverse secondary metabolites.
\end{abstract}

Keywords: marine myxobacteria; metagenomics; uncultured; halophilic organisms; anaerobic; $16 \mathrm{~S}$ rRNA; Sorangiineae; Nannocystineae; Sandaracinaceae related clades; marine myxobacterial clusters

\section{Introduction}

The search for marine myxobacteria began over 50 years ago with the first reports appearing in the 1950s [1-3]. It took until 1998 that the first truly obligate halophilic and halotolerant groups were reported [4-9]. Interest in these species has arisen due to their profound ability to produce secondary metabolites that can serve as leads for drug discovery efforts [10]. Myxobacteria have since been shown to inhabit the marine and estuarine environments often found in sediments or on seagrass and algae [4-8]. Whether they are transient or truly originate from the sea, phylogenetic classifications allow one to determine if a given strain is a halotolerant or halophilic myxobacterium [11]. Strains belonging to the Cystobacterineae-type are predominantly non-halophilic except for halotolerant strains of Myxococcus xanthus, Myxococcus virescens, Myxococcus macrosporus [12], Myxococcus fulvus (strain HW-1) [13], Angiococcus, Corallococcus, and Cystobacter [9]. Isolated myxobacterial strains belonging to the suborder Nannocystineae are unique in that they grow in a wide range of salinity, and hence comprise the obligate halophilic genera Haliangium, Enhygromyxa, and Plesiocystis. 


\section{Phylogenetic Analysis of Cultured Marine- and Estuarine-Derived Myxobacteria}

To date, only five species (Enhygromyxa salina, Haliangium tepidum, H. ochraceum, Plesiocystis pacifica, Pseudenhygromyxa salsuginis), belonging to four new genera of marine and estuarine-derived myxobacteria, have been validly described taxonomically [5-8]. Each of these five strains belong to the Nannocystineae suborder [14]. Application of the BLAST algorithm to identify similar sequences revealed that several additional strains (e.g., Myxobacterium AT1-02, Genbank AB246767; Myxobacterium AT3-09, Genbank AB246768; Bacterium YC-LK-LKJ6, Genbank KP174648) appear to be related to these taxa. That noted, phylogenetic analysis of cultured strains found by BLAST searching reveals a high diversity in the genus Haliangium, Plesiocystis, and Enhygromyxa, with the latter demonstrating the largest number of isolates (Figure 1, Table 1). Strains AT1-02, AT3-09, and YC-LK-LKJ6 cluster with the Enhygromyxa clade, while other strains such as SHI-1 emerged within the Plesiocystis cluster. Myxobacterium strain SMH-27-4 has been suggested as a novel genus and species, Paraliomyxa miuraensis $[15,16]$. On the other hand, the halotolerant and genome sequenced strain Myxococcus fulvus HW-1 [13] appears to be closely related to Myxococcus macrosporus based on $16 \mathrm{~S}$ rRNA gene sequence phylogeny. So far, the culturally described halotolerant myxobacteria were only known in Nannocystineae and Cystobacterineae suborders $[7,9,12]$. However, obligate halophilic strains were exclusively found in Nannocystineae $[5,6,8]$. With the ongoing expanse in this field, it is very likely that new isolates will reveal novel species and genera in Nannocystineae.

\section{Diversity of Myxobacteria in the Suborder Sorangiineae as Inferred from Metagenomic Analyses}

Previous reports have described the diversity of myxobacteria from the marine environment including the exclusive marine myxobacterial cluster (MMC) [17]. The MMC was detected in 6-60\% salinity (sea salt content) indicating their occurrences in brackish (an environment with mixture of fresh and sea water) and marine (referring to the sea or ocean), but not in hypersaline environments. Since this report, more sequences including publicly-deposited JF34-series (GenBank JF344537), KR82-series (GenBank KR825029), and KX0-series (GenBank KX097196) appeared to belong to the MMC cluster. Phylogenetic analysis based on the 16S rRNA gene sequencing revealed that many of these sequences clustered with MMC (Figure 2). Interestingly, many of these clones in the MMC were hypothesized to have an anaerobic lifestyle including AT-s3-66 (GenBank AY225609) and AT-s3-60 (GenBank AY225609) [18]. In addition, clones of the JF34-series clone ANOX-131 (GenBank JF344693) or clone ANOX-089 (GenBank JF344651) [19] were determined to be closely related to MMCf1 and MMCf2 (Figure 2). Since many of these clones were derived from deep sea, methane seeps, and polluted hydrocarbon marine sediments, MMC may potentially comprise an anaerobic group of marine myxobacteria.

Interestingly, Sandaracinaceae related clade (SRC), a neighboring clade to MMC, was shown to be widely distributed in nature (Figure 2). SRC include some of the hydrothermal marine clones PVB_46 (GenBank U15117), described from Pele's vent in Hawaii, and clones V1F160b (GenBank FJ905758) from the Tonga Arc sub-marine volcano [20]. SRC can also be found in coral, marine cyanobacterial blooms, marine seafloor sediments, sea water, mangrove sediments, hypersaline microbial mats, haloalkaline soil, and salt marsh sediment. They have also been observed in terrestrial soils. Members of the SRC are most likely taxonomically divergent as indicated by the phylogenetic distance between its species as well as their ability to thrive in a wide array of habitats.

Together, the MMC and SRC represent interesting clades in the Sorangiineae suborder. To date, only one strain (Sandaracinus amylolyticus DSM $53668{ }^{\mathrm{T}}$ ) has been cultivated from these clades. The diversity in these environments is perhaps comparable with soil myxobacteria in terms of their potential to represent novel genera and families. While not yet achieved, it is reasonable to expect that screening efforts, similar to those developed for soil myxobacteria, will eventually provide an effective growth medium for laboratory culturing. 


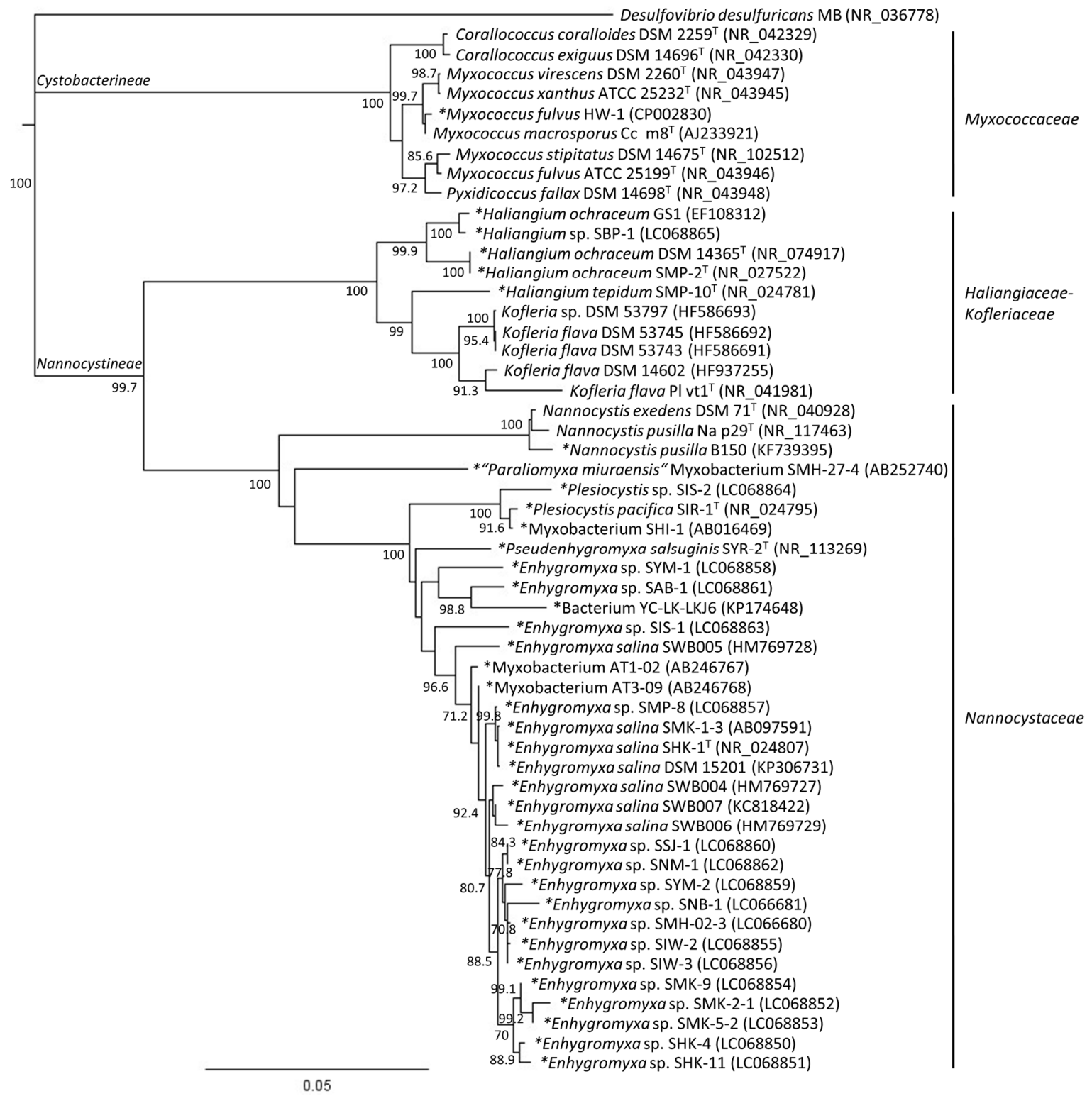

Figure 1. A Neighbor-joining phylogenetic tree inferred from the $16 \mathrm{~S}$ rRNA gene sequence data depicting the position of the cultured myxobacteria in the families Myxococcaceae, Haliangiaceae-Kofleriaceae, and Nannocystaceae derived from saline environments (marked with asterisk). The bar represents 50 nucleotide substitutions per 1000 sites. Bootstrap values greater than $60 \%$ are shown in the nodes (based on 1000 replications). The sequence of Desulfovibrio desulfuricans strain $\mathrm{MB}$ was used as an outgroup to root the tree. ${ }^{\mathrm{T}}$ denotes type strain. Genbank accession numbers are provided in parenthesis. A complete list of the species evaluated has been provided in Table 1. 
Table 1. List of strains and their GenBank accession number.

\begin{tabular}{|c|c|}
\hline Bacterial Strains & GenBank Accession Number \\
\hline Bacterium YC-LK-LKJ6 & KP174648 \\
\hline Corallococcus coralloides DSM $2259^{\mathrm{T}}$ & NR_042329 \\
\hline Corallococcus exiguus DSM $14696^{\mathrm{T}}$ & NR_042330 \\
\hline Desulfovibrio desulfuricans MB & NR_036778 \\
\hline Enhygromyxa sp. SAB-1 & LC068861 \\
\hline Enhygromyxa salina $\mathrm{SHK}-\mathrm{1}^{\mathrm{T}}$ & NR_024807 \\
\hline Enhygromyxa sp. SHK-4 & LC068850 \\
\hline Enhygromyxa sp. SHK-11 & LC068851 \\
\hline Enhygromyxa sp. SIS-1 & LC068863 \\
\hline Enhygromyxa sp. SIW-2 & LC068855 \\
\hline Enhygromyxa sp. SIW-3 & LC068856 \\
\hline Enhygromyxa sp. SMH-02-3 & LC066680 \\
\hline Enhygromyxa salina SMK-1-3 & AB097591 \\
\hline Enhygromyxa sp. SMK-2-1 & LC068852 \\
\hline Enhygromyxa sp. SMK-5-2 & LC068853 \\
\hline Enhygromyxa sp. SMK-9 & LC068854 \\
\hline Enhygromyxa sp. SMP-8 & LC068857 \\
\hline Enhygromyxa sp. SNB-1 & LC066681 \\
\hline Enhygromyxa sp. SNM-1 & LC068862 \\
\hline Enhygromyxa sp. SSJ-1 & LC068860 \\
\hline Enhygromyxa sp. SYM-1 & LC068858 \\
\hline Enhygromyxa sp. SYM-2 & LC068859 \\
\hline Enhygromyxa salina DSM 15201 & KP306731 \\
\hline Enhygromyxa salina SWB004 & HM769727 \\
\hline Enhygromyxa salina SWB005 & HM769728 \\
\hline Enhygromyxa salina SWB006 & HM769729 \\
\hline Enhygromyxa salina SWB007 & KC818422 \\
\hline Haliangium sp. SBP-1 & LC068865 \\
\hline Haliangium ochraceum GS1 & EF108312 \\
\hline Haliangium ochraceum DSM $14365^{\mathrm{T}}$ & NR_074917 \\
\hline Haliangium ochraceum SMP-2 T & NR_027522 \\
\hline Haliangium tepidum SMP-10 ${ }^{\mathrm{T}}$ & NR_024781 \\
\hline Kofleria sp. DSM 53797 & HF586693 \\
\hline Kofleria flava DSM 53745 & HF586692 \\
\hline Kofleria flava DSM 53743 & HF586691 \\
\hline Kofleria flava DSM 14602 & HF937255 \\
\hline Kofleria flava $\mathrm{Pl} \mathrm{vt} 1^{\mathrm{T}}$ & NR_041981 \\
\hline Myxobacterium SHI-1 & AB016469 \\
\hline Myxobacterium SMH-27-4 ("Paraliomyxa miuraensis") * & AB252740 \\
\hline Myxobacterium AT1-02 & AB246767 \\
\hline Myxobacterium AT3-09 & AB246768 \\
\hline Myxococcus fulvus HW-1 & СР002830 \\
\hline Myxococcus fulvus ATCC $25199^{\mathrm{T}}$ & NR_043946 \\
\hline Myxococcus macrosporus $\mathrm{Cc} \mathrm{m} 8^{\mathrm{T}}$ & AJ233921 \\
\hline Myxococcus stipitatus DSM $14675^{\mathrm{T}}$ & NR_102512 \\
\hline Myxococcus virescens DSM $2260^{\mathrm{T}}$ & NR_043947 \\
\hline Myxococcus xanthus ATCC $25232^{\mathrm{T}}$ & NR_043945 \\
\hline Nannocystis exedens DSM $71^{\mathrm{T}}$ & NR 040928 \\
\hline Nannocystis pusilla Na p29 ${ }^{\mathrm{T}}$ & NR_117463 \\
\hline Nannocystis pusilla B150 & KF739395 \\
\hline Plesiocystis pacifica SIR-1 ${ }^{\mathrm{T}}$ & NR_024795 \\
\hline Plesiocystis sp. SIS-2 & LC068864 \\
\hline Pseudenhygromyxa salsuginis SYR-2 ${ }^{\mathrm{T}}$ & NR_113269 \\
\hline Pyxidicoccus fallax DSM $14698^{\mathrm{T}}$ & NR_043948 \\
\hline
\end{tabular}

${ }^{*}$ Tentative name proposal based on reference 15 and 16 and ${ }^{\mathrm{T}}$ denotes type strain. 

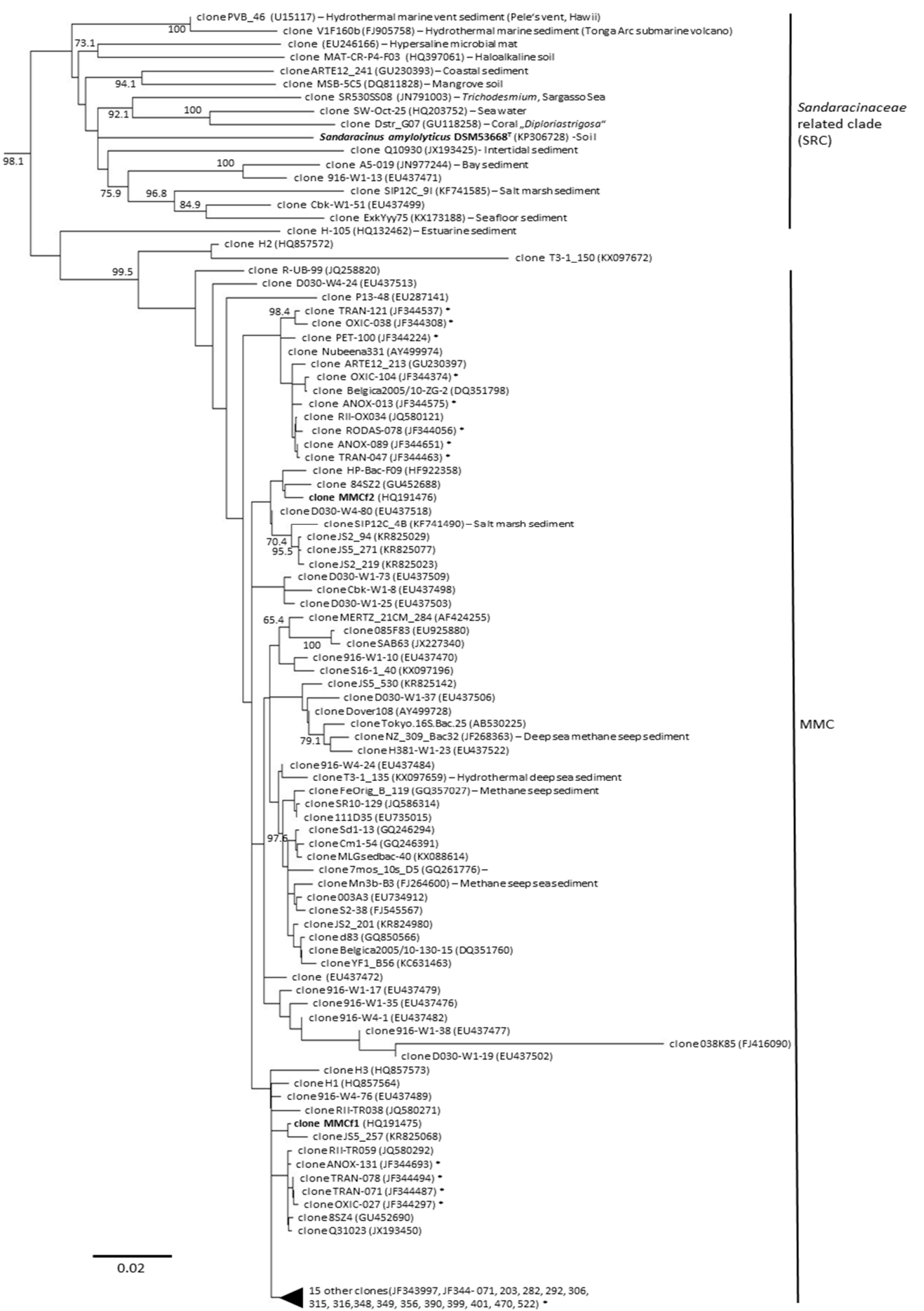

Figure 2. A phylogenetic tree inferred from the 16S rRNA gene sequence acquired from metagenomic analyses depicting the diversity of myxobacteria in Sorangiineae suborder observed in salt-containing environments. Unless indicated, the sequences were obtained from marine sediments. The GenBank accession number is indicated in parenthesis. JF34 (marked in asterisk) represents bacteria that likely grow anaerobically. The bar represents 20 nucleotide substitutions per 1000 sites. Bootstrap values greater than $60 \%$ are shown in the nodes (based on 1000 replications). 


\section{Diversity of Myxobacteria in the Nannocystineae Suborder}

Our understanding of marine myxobacteria arises from studies on strains in the suborder Nannocystineae. However, they only occupy a small percentage of the total diversity, as the majority remains yet to be cultivated under laboratory conditions. Understanding the "uncultured" members of this suborder lies at the forefront of current discovery efforts. Truly halophilic myxobacterial isolates are typically classified as belonging to the genera Haliangium, Plesiocystis, and Enhygromyxa, while the halotolerant isolates belong to the genus Pseudenhygromyxa in Nannocystineae suborder. By exploration of $16 \mathrm{~S}$ rRNA metagenomics and phylogeny, the Nannocystineae clade is far more environmentally diverse when compared with Sorangiineae. Currently, the diversity of uncultured myxobacteria in this suborder spans from saline-alkaline soil, mangrove soil, hypersaline mats, estuarine sediments to reef, marine and deep sea sediments. Overall, the issue then arises as to how one can gain access to species that have adapted a very specific environmental niche.

As shown in Figure 3, this suborder is divided into major clades I and II. Clade I includes members of the isolated myxobacterial strains in the genera Enhygromyxa, Pseudenhygromyxa, Nannocystis, Haliangium, and Kofleria. It also contains several isolates that have not yet been validated taxonomically. A large portion of the clade I cluster is comprised of yet uncultured species in the Haliangium-Kofleria subclade. This subclade contains the highest level of diversity and arises from deep sea [21,22] and estuarine sediments [23]. Clade II differs from clade I in the fact that not a single isolate has yet been cultured. Clade II species are found throughout a wide variety of different saline ecosystems [19,24-28].

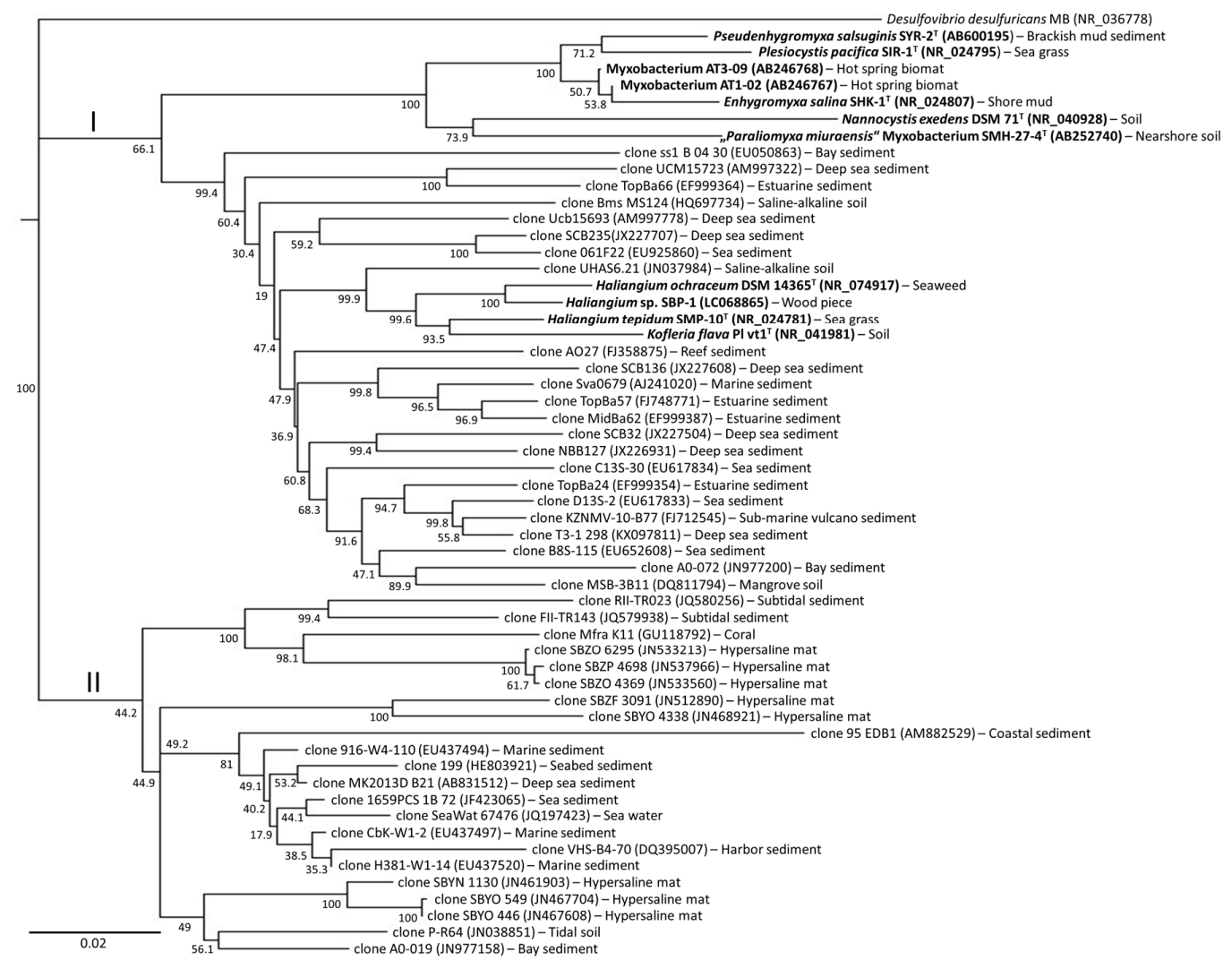

Figure 3. A Neighbor-joining phylogenetic tree inferred from the 16S rRNA gene sequence illustrating the diversity of myxobacteria in the Nannocystineae suborder from various salt-containing environments. Cultivated halotolerant or halophilic myxobacteria and their corresponding representative type strains are shown in bold-face. GenBank accession number is indicated in parenthesis. The sample source is shown after the accession number. The bar represents 20 nucleotide substitutions per 1000 sites. Bootstrap values are shown in the nodes based on 1000 replications. The sequence of Desulfovibrio desulfuricans strain $\mathrm{MB}$ was used as an outgroup to root the tree. 


\section{Characteristics of Novel Marine Myxobacteria and Parameters to Consider for Their Cultivation}

Based on metagenomics data and phylogenetic classification, uncultured marine myxobacteria exhibit some of the following characteristics.

\subsection{Structural Features: Rod-Shaped Cells with Blunted Ends}

Strains classified within Sorangiineae and Nannocystineae typically exhibit rod-shaped cells with blunted ends (Figure 4a). These suborders are unique for this type of cell shape. Such cells can be differentiated from strains belonging to the Cystobacterineae suborder [29], for which vegetative cells appear as thinner flexuous rods. The uncultured marine Sorangiineae and Nannocystineae cells may have adapted to their aquatic environment to become motile.

\subsection{Reproductive Features: Reduction in Forming Fruiting Bodies}

Studies to date have shown that fruiting body formation in select halotolerant strains is supported by up to $60 \% w / v$ seawater (equivalent to $2 \% w / v$ salt in solid medium) [9]. Other studies, however, have shown that fruiting body-bearing spores from halophilic strains including Haliangium tepidum [8,30], Enhygromyxa salina [5,31], and Plesiocystis pacifica $[6,31]$ can still be observed at sea water salinity $(\sim 3.5 \% w / v)$. Isolation of novel myxobacteria from salt environments should not rely completely on the appearance of fruiting bodies, as this structure may not develop. Further studies have shown that strains belonging to the SRC may not form fruiting bodies as exemplified by Sandaracinus within this clade [32].

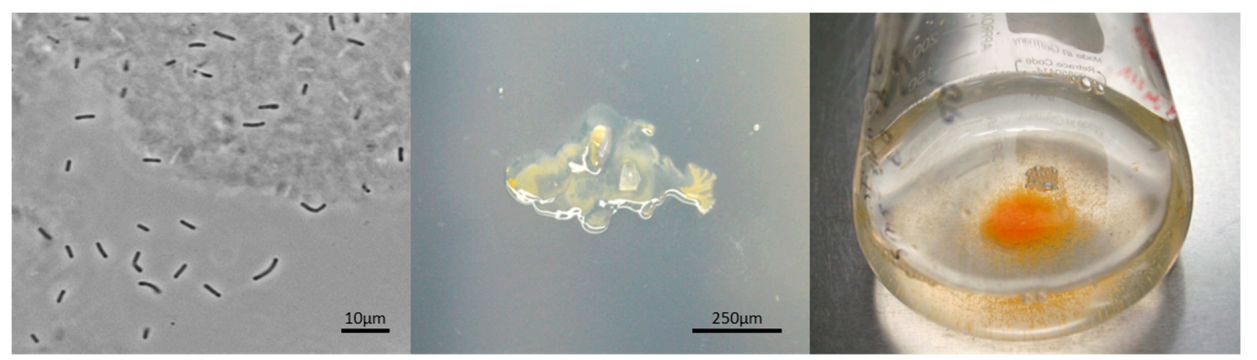

(a)

(b)

(c)

Figure 4. Predicted growth morphology characteristics of a marine myxobacteria in Sorangiineae suborder. The species name has not yet been assigned. (a) Phase-contrast photomicrograph of vegetative rod cells with blunted ends, (b) Stereophotograph of a colony showing the pattern of agar degradation, (c) Growth in liquid medium containing sea salts showing some cell aggregates after shaking.

\subsection{Chemical Predation and Defense: Lack of Microbial Predation and Cellulose Degradation but Agar Degradation}

Based on metagenomic analysis of salt-containing environments, uncultured myxobacteria appear to belong to the suborders Sorangiineae (Figure 2) and Nannocystineae (Figure 3). Since these suborders are known for agar degradation, one might expect that these myxobacteria may also share this characteristic (Figure 4b). Microbial lysis is known in myxobacteria, however, this trait may be lost in samples derived from deep sea ecosystems. Since strains have yet to be obtained from deep sea sediments, it is not known whether these myxobacteria can prey on other microorganisms. So far, none of the Nannocystineae isolated to date degrade cellulose, an observation, which is commonly found in terrestrial strains.

\subsection{Requirement for Salinity: A Need for Salt and Associate Metal Cations}

Marine-derived myxobacteria differ from terrestrial isolates primarily in their salt tolerance (Figure 4c). They seem to have adapted a system to adjust to saline environments using osmolytes such 
as ectoine, hydroxyectoine, and glycine betaine [33]. In halotolerant Myxococcus strains, salt tolerance was speculated to be acquired by horizontal hdsp gene transfer [34], while Plesiocystis pacifica SIR-I strain makes use of amino acids as osmoprotectant [35]. In addition to modulation of salt levels, isolated marine myxobacteria typically require the addition of cations such as $\mathrm{Ca}^{2+}, \mathrm{Mg}^{2+}$, and $\mathrm{K}^{+}$to support growth.

\subsection{Temperature Regulation: Growth Possible in Wider Temperature Range}

To date, the isolated marine and estuarine-derived myxobacteria grew at a wider temperature range $\left(5-45^{\circ} \mathrm{C}\right)[5,8,31]$ than terrestrial species. While the aqueous environment of marine species plays a key role in temperature regulation, it is likely that they have highly adapted and evolved to match the temperature of their local environment. For instance, tropical sandy beaches will likely contain marine myxobacteria, which can resist higher temperatures [8] than those collected in frigid seas in the North Atlantic [17].

\subsection{Life Cycle: Potentially Slow Growth}

Since metagenomic and phylogenetic data revealed that novel myxobacteria in salt-containing environments were positioned in the Sorangiineae and Nannocystineae suborders, it might be expected that they grow much slower when compared with most terrestrial counterparts. In general, cultured members of these suborders may be recognized by their growth after weeks of incubation in the isolation set-ups. One might speculate that these organisms may be microaerophilic, anaerobic, and utilize different carbon sources such as methane, since many of these clones were derived from hydrothermal vents, sub-marine volcanic ash, and deep sea seep sediments.

\section{Can Marine Myxobacteria Access Novel Bioactive Secondary Metabolites?}

Marine-derived myxobacteria have already demonstrated a strong potential to produce natural products with distinct scaffolds [36-41]. Many of these materials display unique structure features as exemplified by the enhygrolides [36], enhygromic acid [37], haliamide [38], haliangicin [39,40], miuraenamide [15,16], salimabromide [41], and the salimyxins [36] (the structures of these materials are provided in the accompaning manuscript [10]). Many of these materials have demonstrated potent biological activity [42]. For instance, enhygrolide A was shown by the König laboratory to inhibit the growth of the Gram-positive bacterium at microgram concentration (MIC, $4 \mu \mathrm{g} \mathrm{mL}^{-1}$ against Arthrobacter cristallopoietes) [36]. Other studies including those on enhygromic acid ( $\mathrm{IC}_{50}$ value of $46 \mu \mathrm{M}, \mathrm{B} 16$ melanoma cells) [37] or haliamide (12 $\mu \mathrm{M}$, HeLa-S3 cells) [38] have shown activities against the proliferation of tumor cells. Studies on haliangicin have identified antifungal activities with minimal inhibitory concentration (MIC) values comparable to amphotericin and nystatin [40]. While the modes of action of these compounds still remain unexplored, morphology screening efforts identified actin filament stabilizing activity associated with miuraenamide A [43]. While early on, the evidence collected to date indicates that unique bioactive scaffolds can be obtained from marineand estuarine-derived myxobacteria.

A large percentage of marine myxobacterial strains remain uncultured to-date, as access to these strains remains challenging under laboratory conditions. Furthermore, the potential to produce novel compounds by marine myxobacteria is also reflected in the diversity of the biosynthetic gene clusters encoded in the few available genome sequences [44,45]. Previous studies have shown novel Type I polyketide synthase genes that can be found in marine myxobacteria [46], which indicates the potential of these organisms to produced novel compounds. A further description of the unique complexity of these synthases and their associated natural products has recently been reviewed [10].

\section{Conclusions}

Myxobacteria appear to be ubiquitous and diverse in nature, and are not just terrestrial but found in marine, estuarine, and a variety of other saline ecosystems. Metagenomic analyses indicate that the 
marine myxobacteria identified to date occupy only a small portion of the potential Nannocystineae phylogenetic tree. This suggests that a vast diversity of species are unexplored. The development of new methods and tools to culture these species would unveil a yet untapped and robust potential. This, combined with the well-established ability of myxobacteria to produce unique and bioactive molecules, identifies the suborder Nannocystineae as an important resource for future therapeutic evaluation. The suborder Sorangiineae also holds great promise for natural product discoveries. Currently, not a single species of the exclusively MMC have been isolated and cultured. In addition, the SRC appears interesting since it is not well explored and also seems distributed through a vast array of marine environments. Based on metagenomic and phylogenetic analysis, those clones derived from marine deep-sea sediments may return extremophilic myxobacteria with access to halophilic, anaerobic, microaerophilic, piezophilic, or psychrophilic properties. Finding the requirements for salinity, salts, temperature, and dissolved gasses is obviously necessary. Simulating the conditions of an organism's natural environment is likely key to the successful cultivation of marine myxobacteria. This observation suggests that we explore the development of laboratory culturing systems that operate at sea. Here, one can envision the development of robotic devices that mimic the natural conditions in marine ecosystems such as that in a sponge [47]. Recent discoveries clearly indicate that marine myxobacteria are under explored group of organisms that offer tremendous potential for secondary metabolite and molecular mining, either through the advance of modern devices or classical approaches.

Author Contributions: R.G. searched for the 16S rRNA gene sequences by BLAST and constructed the phylogenetic trees. R.G., J.J.L.C., and R.M. analyzed data, wrote the manuscript and edited it.

Acknowledgments: We thank the German Center for Infection Research (Deutsches Zentrum für Infektionsforschung, DZIF) for continuous support on anti-infective research (to R.M.) and the Xenobe Research Institute (to J.J.L.C.)

Conflicts of Interest: The authors declare no conflict of interest.

\section{References}

1. Starr, T.J.; Ordal, E.J. A Study of Marine Myxobacteria; Technical Report for University of Washington Department of Oceanography: Seattle, WA, USA, December 1953.

2. Brockman, E.R. Fruiting myxobacteria from the South Carolina coast. J. Bacteriol. 1967, 94, 1253-1254. [PubMed]

3. Rückert, G. Zur Verbreitung von Fruchtkörper-bildenden Myxobakterien in europäischen Strand- und Dünenböden. Zentralbl. Bakteriol. Parasitenkd. Infektionskr. Hyg. 1975, 130, 343-347. [CrossRef]

4. Iizuka, T.; Jojima, Y.; Fudou, R.; Yamanaka, S. Isolation of myxobacteria from the marine environment. FEMS Microbiol. Lett. 1998, 169, 317-322. [CrossRef] [PubMed]

5. Iizuka, T.; Jojima, Y.; Fudou, R.; Tokura, M.; Hiraishi, A.; Yamanaka, S. Enhygromyxa salina gen. nov., sp. nov., a slightly halophilic myxobacterium isolated from the coastal areas of Japan. Syst. Appl. Microbiol. 2003, 26, 189-196. [CrossRef] [PubMed]

6. Iizuka, T.; Jojima, Y.; Fudou, R.; Hiraishi, A.; Ahn, J.W.; Yamanaka, S. Plesiocystis pacifica gen. nov., sp. nov., a marine myxobacterium that contains dihydrogenated menaquinone, isolated from the pacific coasts of Japan. Int. J. Syst. Evol. Microbiol. 2003, 53, 189-195. [CrossRef] [PubMed]

7. Iizuka, T.; Jojima, Y.; Hayakawa, A.; Fujii, T.; Yamanaka, S.; Fudou, R. Pseudenhygromyxa salsuginis gen. nov., sp. nov., a myxobacterium isolated from an estuarine marsh. Int. J. Syst. Evol. Microbiol. 2013, 63, 1360-1369. [CrossRef] [PubMed]

8. Fudou, R.; Jojima, Y.; Iizuka, T.; Yamanaka, S. Haliangium ochraceum gen. nov., sp nov and Haliangium tepidum sp nov.: Novel moderately halophilic myxobacteria isolated from coastal saline environments. J. Gen. Appl. Microbiol. 2002, 48, 109-115. [CrossRef] [PubMed]

9. Li, Y.Z.; Hu, W.; Zhang, Y.Q.; Qiu, Z.; Zhang, Y.; Wu, B.H. A simple method to isolate salt-tolerant myxobacteria from marine samples. J. Microbiol. Methods 2002, 50, 205-209. [CrossRef]

10. Gemperlein, K.; Zaburannyi, N.; Garcia, R.; La Clair, J.J.; Müller, R. Metabolic and biosynthetic diversity in marine myxobacteria. Mar. Drugs 2018, in press.

11. Jiang, D.M.; Kato, C.; Zhou, X.W.; Wu, Z.H.; Sato, T.; Li, Y.Z. Phylogeographic separation of marine and soil myxobacteria at high levels of classification. ISME J. 2010, 4, 1520-1530. [CrossRef] [PubMed] 
12. Garcia, R.; Müller, R. The Family Myxococcaceae. In The Prokaryotes: Deltaproteobacteria and Epsilonproteobacteria; Rosenberg, E., DeLong, E.F., Lory, S., Stackebrandt, E., Thompson, F., Eds.; Springer: Berlin/Heidelberg, Germany, 2014; pp. 191-212.

13. Li, Z.F.; Li, X.; Liu, H.; Liu, X.; Han, K.; Wu, Z.H.; Hu, W.; Li, F.F.; Li, Y.Z. Genome sequence of the halotolerant marine bacterium Myxococcus fulvus HW-1. J. Bacteriol. 2011, 193, 5015-5016. [CrossRef] [PubMed]

14. Garcia, R.; Gerth, K.; Stadler, M.; Dogma, I.J., Jr.; Müller, R. Expanded phylogeny of myxobacteria and evidence for cultivation of the 'unculturables'. Mol. Phylogenet. Evol. 2010, 57, 878-887. [CrossRef] [PubMed]

15. Ojika, M.; Inukai, Y.; Kito, Y.; Hirata, M.; Iizuka, T.; Fudou, R. Miuraenamides: Antimicrobial cyclic depsipeptides isolated from a rare and slightly halophilic myxobacterium. Chem. Asian J. 2008, 3, 126-133. [CrossRef] [PubMed]

16. Iizuka, T.; Fudou, R.; Jojima, Y.; Ogawa, S.; Yamanaka, S.; Inukai, Y.; Ojika, M. Miuraenamides A and B, novel antimicrobial cyclic depsipeptides from a new slightly halophilic myxobacterium: Taxonomy, production, and biological properties. J. Antibiot. 2006, 59, 385-391. [CrossRef] [PubMed]

17. Brinkhoff, T.; Fischer, D.; Vollmers, J.; Voget, S.; Beardsley, C.; Thole, S.; Mussmann, M.; Kunze, B.; Wagner-Döbler, I.; Daniel, R.; Simon, M. Biogeography and phylogenetic diversity of a cluster of exclusively marine myxobacteria. ISME J. 2012, 6, 1260-1272. [CrossRef] [PubMed]

18. López-García, P.; Duperron, S.; Philippot, P.; Foriel, J.; Susini, J.; Moreira, D. Bacterial diversity in hydrothermal sediment and epsilonproteobacterial dominance in experimental microcolonizers at the Mid-Atlantic Ridge. Environ. Microbiol. 2003, 5, 961-976. [CrossRef] [PubMed]

19. Acosta-González, A.; Rosselló-Móra, R.; Marqués, S. Characterization of the anaerobic microbial community in oil-polluted subtidal sediments: Aromatic biodegradation potential after the Prestige oil spill. Environ. Microbiol. 2013, 15, 77-92. [CrossRef] [PubMed]

20. Forget, N.L.; Murdock, S.A.; Juniper, S.K. Bacterial diversity in Fe-rich hydrothermal sediments at two South Tonga Arc submarine volcanoes. Geobiology 2010, 8, 417-432. [CrossRef] [PubMed]

21. Wu, Y.H.; Liao, L.; Wang, C.S.; Ma, W.L.; Meng, F.X.; Wu, M.; Xu, X.W. A comparison of microbial communities in deep-sea polymetallic nodules and the surrounding sediments in the Pacific Ocean. Deep Sea Res. Part I 2013, 79, 40-49. [CrossRef]

22. Schauer, R.; Bienhold, C.; Ramette, A.; Harder, J. Bacterial diversity and biogeography in deep-sea surface sediments of the South Atlantic Ocean. ISME J. 2010, 4, 159-170. [CrossRef] [PubMed]

23. Jiang, L.; Zheng, Y.; Peng, X.; Zhou, H.; Zhang, C.; Xiao, X.; Wang, F. Vertical distribution and diversity of sulfate-reducing prokaryotes in the Pearl River estuarine sediments, Southern China. FEMS Microbiol. Ecol. 2009, 70, 93-106. [CrossRef] [PubMed]

24. Zhang, W.; Ki, J.S.; Qian, P.Y. Microbial diversity in polluted harbor sediments I: Bacterial community assessment based on four clone libraries of 16S rDNA. Estuar. Coast. Shelf Sci. 2008, 76, 668-681. [CrossRef]

25. Aoki, M.; Ehara, M.; Saito, Y.; Yoshioka, H.; Miyazaki, M.; Saito, Y.; Miyashita, A.; Kawakami, S.; Yamaguchi, T.; Ohashi, A.; et al. A long-term cultivation of an anaerobic methane-oxidizing microbial community from deep-sea methane-seep sediment using a continuous-flow bioreactor. PLoS ONE 2014, 9, e105356. [CrossRef] [PubMed]

26. Paissé, S.; Coulon, F.; Goñi-Urriza, M.; Peperzak, L.; McGenity, T.J.; Duran, R. Structure of bacterial communities along a hydrocarbon contamination gradient in a coastal sediment. FEMS Microbiol. Ecol. 2008, 66, 295-305. [CrossRef] [PubMed]

27. Harris, J.K.; Caporaso, J.G.; Walker, J.J.; Spear, J.R.; Gold, N.J.; Robertson, C.E.; Hugenholtz, P.; Goodrich, J.; McDonald, D.; Knights, D.; et al. Phylogenetic stratigraphy in the Guerrero Negro hypersaline microbial mat. ISME J. 2013, 7, 50-60. [CrossRef] [PubMed]

28. Sunagawa, S.; Woodley, C.M.; Medina, M. Threatened corals provide underexplored microbial habitats. PLoS ONE 2010, 5, e9554. [CrossRef] [PubMed]

29. Reichenbach, H. Order VIII. Myxococcales. Tchan, Pochon and Prévot 1948, 398AL. In Bergey's Manual ${ }^{\circledR}$ of Systematic Bacteriology, 2nd ed.; Garrity, G., Brenner, D.J., Krieg, N.R., Staley, J.T., Eds.; Springer: New York, NY, USA, 2005; Volume 2, Part C; pp. 1059-1144.

30. Garcia, R.; Müller, R. The Family Haliangiaceae. In The Prokaryotes; Rosenberg, E., DeLong, E.F., Lory, S., Stackebrandt, E., Thompson, F., Eds.; Springer: Berlin/Heidelberg, Germany, 2014; pp. 173-181.

31. Garcia, R.; Müller, R. The Family Nannocystaceae. In The Prokaryotes; Rosenberg, E., DeLong, E.F., Lory, S., Stackebrandt, E., Thompson, F., Eds.; Springer: Berlin/Heidelberg, Germany, 2014; pp. 213-229. 
32. Mohr, K.I.; Garcia, R.O.; Gerth, K.; Irschik, H.; Müller, R. Sandaracinus amylolyticus gen. nov., sp. nov., a starch-degrading soil myxobacterium, and description of Sandaracinaceae fam. nov. Int. J. Syst. Evol. Microbiol. 2012, 62, 1191-1198. [CrossRef] [PubMed]

33. Kimura, Y.; Kawasaki, S.; Yoshimoto, H.; Takegawa, K. Glycine betaine biosynthesized from glycine provides an osmolyte for cell growth and spore germination during osmotic stress in Myxococcus xanthus. J. Bacteriol. 2010, 192, 1467-1470. [CrossRef] [PubMed]

34. Pan, H.W.; Tan, Z.G.; Liu, H.; Li, Z.F.; Zhang, C.Y.; Li, C.Y.; Li, J.; Li, Y.Z. Hdsp, a horizontally transferred gene required for social behavior and halotolerance in salt-tolerant Myxococcus fulvus HW-1. ISME J. 2010, 4, 1282-1289. [CrossRef] [PubMed]

35. Moghaddam, J.A.; Boehringer, N.; Burdziak, A.; Kunte, H.J.; Galinski, E.A.; Schäberle, T.F. Different strategies of osmoadaptation in the closely related marine myxobacteria Enhygromyxa salina SWB007 and Plesiocystis pacifica SIR-1. Microbiology 2016. [CrossRef] [PubMed]

36. Felder, S.; Kehraus, S.; Neu, E.; Bierbaum, G.; Schäberle, T.F.; König, G.M. Salimyxins and enhygrolides: Antibiotic, sponge-related metabolites from the obligate marine myxobacterium Enhygromyxa salina. ChemBioChem 2013, 14, 1363-1371. [CrossRef] [PubMed]

37. Tomura, T.; Nagashima, S.; Yamazaki, S.; Iizuka, T.; Fudou, R.; Ojika, M. An unusual diterpene-enhygromic acid and deoxyenhygrolides from a marine myxobacterium, Enhygromyxa sp. Mar. Drugs 2017, 15, 109. [CrossRef] [PubMed]

38. Sun, Y.; Tomura, T.; Sato, J.; Iizuka, T.; Fudou, R.; Ojika, M. Isolation and biosynthetic analysis of haliamide, a new PKS-NRPS hybrid metabolite from the marine myxobacterium Haliangium ochraceum. Molecules 2016, 21, 59. [CrossRef] [PubMed]

39. Fudou, R.; Iizuka, T.; Sato, S.; Ando, T.; Shimba, N.; Yamanaka, S. Haliangicin, a novel antifungal metabolite produced by a marine myxobacterium. 2. Isolation and structural elucidation. J. Antibiot. 2001, 54, 153-156. [CrossRef] [PubMed]

40. Fudou, R.; lizuka, T.; Yamanaka, S. Haliangicin, a novel antifungal metabolite produced by a marine myxobacterium. 1. Fermentation and biological characteristics. J. Antibiot. 2001, 54, 149-152. [CrossRef] [PubMed]

41. Felder, S.; Dreisigacker, S.; Kehraus, S.; Neu, E.; Bierbaum, G.; Wright, P.R.; Menche, D.; Schäberle, T.F.; König, G.M. Salimabromide: Unexpected chemistry from the obligate marine myxobacterium Enhygromxya salina. Chemistry 2013, 19, 9319-9324. [CrossRef] [PubMed]

42. Davila-Cespedes, A.; Hufendiek, P.; Crusemann, M.; Schaberle, T.F.; Konig, G.M. Marine-derived myxobacteria of the suborder Nannocystineae: An underexplored source of structurally intriguing and biologically active metabolites. Beilstein J. Org. Chem. 2016, 12, 969-984. [CrossRef] [PubMed]

43. Sumiya, E.; Shimogawa, H.; Sasaki, H.; Tsutsumi, M.; Yoshita, K.; Ojika, M.; Suenaga, K.; Uesugi, M. Cell-morphology profiling of a natural product library identifies bisebromoamide and miuraenamide $\mathrm{A}$ as actin filament stabilizers. ACS Chem. Biol. 2011, 6, 425-431. [CrossRef] [PubMed]

44. Moghaddam, J.A.; Poehlein, A.; Fisch, K.; Alanjary, M.; Daniel, R.; König, G.M.; Schäberle, T.F. Draft Genome Sequences of the Obligatory Marine Myxobacterial Strains Enhygromyxa salina SWB005 and SWB007. Genome Announc. 2018, 6, e00324-18. [CrossRef] [PubMed]

45. Ivanova, N.; Daum, C.; Lang, E.; Abt, B.; Kopitz, M.; Saunders, E.; Lapidus, A.; Lucas, S.; Glavina Del Rio, T.; Nolan, M.; et al. Complete genome sequence of Haliangium ochraceum type strain (SMP-2). Stand. Genom. Sci. 2010, 2, 96-106. [CrossRef] [PubMed]

46. Komaki, H.; Fudou, R.; Iizuka, T.; Nakajima, D.; Okazaki, K.; Shibata, D.; Ojika, M.; Harayama, S. PCR detection of type I polyketide synthase genes in myxobacteria. Appl. Environ. Microbiol. 2008, 74, 5571-5574. [CrossRef] [PubMed]

47. La Clair, J.J.; Loveridge, S.T.; Tenney, K.; O’Neil-Johnson, M.; Chapman, E.; Crews, P. In situ natural product discovery via an artificial marine sponge. PLOS ONE 2014, 9, e100474. [CrossRef] [PubMed]

(C) 2018 by the authors. Licensee MDPI, Basel, Switzerland. This article is an open access article distributed under the terms and conditions of the Creative Commons Attribution (CC BY) license (http:/ / creativecommons.org/licenses/by/4.0/). 